\title{
Innovative transportable laboratories for polar science
}

\section{Liesbeth H.W. Noor}

NWO, Laan van NOI 300, 2593 CE Den Haag, the Netherlands; Current address: Department of Biology, Utrecht University, the Netherlands (lhwnoor@yahoo.co.uk)

\section{Dick A. van der Kroef}

NWO, Laan van NOI 300, 2593 CE Den Haag, the Netherlands

\section{David Wattam}

British Antarctic Survey, NERC, High Cross, Madingley Road, Cambridge CB3 OET, UK

\section{Michael Pinnock}

British Antarctic Survey, NERC, High Cross, Madingley Road, Cambridge CB3 OET, UK

\section{Ronald van Rossum}

JM Services, Watertoren 11, 3247 CL Dirksland, the Netherlands

\section{Marck G. Smit}

NIOZ Royal Netherlands Institute for Sea Research, Landsdiep 4, 1797 SZ 't Horntje, Texel, the Netherlands

\section{Corina P.D. Brussaard}

NIOZ Royal Netherlands Institute for Sea Research, Department of Microbiology and Biogeochemistry, and Utrecht University, Landsdiep 4, 1797 SZ 't Horntje, Texel, the Netherlands

Received October 2017; first published online 26 March 2018

\begin{abstract}
The Netherlands Organisation for Scientific Research and the British Antarctic Survey have built a transportable laboratory facility, named the Dirck Gerritsz Laboratory, to accommodate new scientific research on and from the western Antarctic Peninsula. The design provides a flexible, modular, plug-and-play, innovative and sustainable laboratory setup. The docking station houses four 20-foot ISO standard high-cube containers, each of which contains a different laboratory. Special technological features were used to minimise the environmental impact. The four laboratory containers are flexible and can be installed and used as required, and renewed or removed when necessary. The container laboratories have provided, since opening in 2013, enhanced facilities for global climate change research through studying the community composition of phytoplankton; the ecological impact of virus-induced mortality in different phytoplankton groups; dimethylsulphide and brominated compound fluxes; and $\mathrm{CO}_{2}$ concentrations and trace elements in sea water. Transportable research laboratory facilities provide an effective and efficient approach for undertaking scientific research in challenging environments and might be the start of a new way of undertaking research, including exchanging laboratory modules between research stations in Antarctica.
\end{abstract}

\section{Introduction}

Polar research has many constraints besides the extreme weather conditions. Researchers from countries without an established research facility in Antarctica depend heavily on the logistical support of partners. The scientific tradition of the Netherlands led Dutch scientists to Antarctica, but rather than building its own infrastructure the Netherlands developed a way of operating in Antarctica and engaging with Antarctic research through collaboration. This has resulted in a variety of collaborations with different international partners in polar science. A long-lasting and fruitful relationship between the British Antarctic Survey (BAS) and the Netherlands Organisation for Scientific Research (NWO) exists that promotes research projects executed from Antarctic research stations.
In 1995 this collaboration was recorded in a memorandum of understanding between both parties. Furthermore, this kind of liaison is very much as advocated by the Scientific Committee for Antarctic Research (Kennicutt, 2009). Combining the operational practices and capabilities of different research parties will not only lead to better science, but is also a way to use infrastructure and equipment in an efficient manner. To optimise the joint research programme, the decision was made to invest in this alliance by realising, in a collaborative effort, a specialised transportable laboratory facility at Rothera Research Station that could accommodate new scientific research topics. Rothera Research Station is situated on the Antarctic Peninsula, a region known for its rapid regional climate warming (Meredith \& King, 2005; Vaughan et al., 


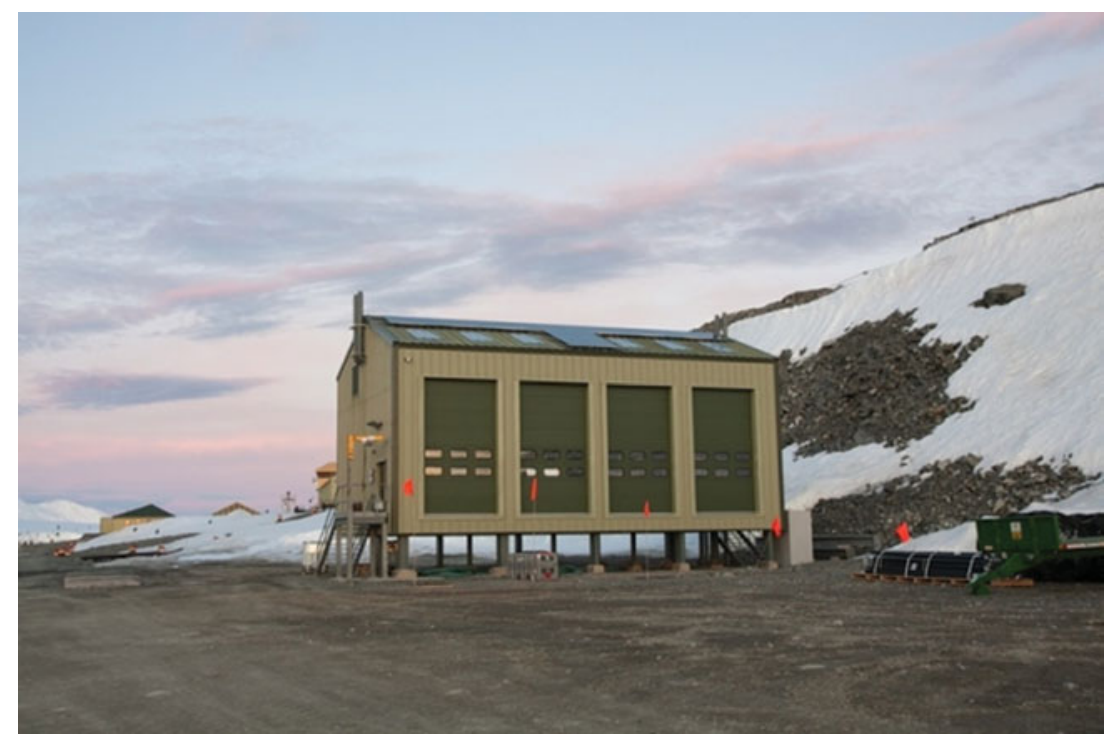

Fig. 1. The Dirck Gerritsz Laboratory at Rothera Research Station. Photo: G. Kulk

2003). As Dutch polar research has a major focus on climate impact, this location is particularly suitable. BAS has conducted a long-term oceanographic monitoring programme from Rothera Station for 20 years (Meredith et al., 2017), thus providing foundation measurements upon which detailed process studies could be designed by the Dutch initiative. The aim was to construct complementary facilities that were not yet available within the BAS research programme and station, that were close to the sea, provided ready access to near-shore sampling facilities, and that allowed analysis and incubation of fresh samples. The new research facility is transportable, which widens the possibilities for its use, for example it can be moved elsewhere within the Antarctic continent, to the Arctic region or on-board research vessels. This concept and the technology it employs reduces the footprint of scientific research on this pristine continent.

Inspired by innovative 20 -foot container laboratories routinely deployed on the University-National Oceanographic Laboratory System (UNOLS) in the USA, the Ocean Facilities Exchange Group (OFEG) in Europe and other research vessels, a flexible, modular, plug-and-play, innovative and sustainable laboratory setup was built, named the Dirck Gerritsz Laboratory (see Figs $1 \& 2$; see De Baar 2013 for the story behind the name). Working from the BAS Rothera Research Station enables Dutch scientists to operate alongside British scientists in a collaborative and complementary manner resulting in joint scientific papers. The technological features of the Dirck Gerritsz Laboratory allow it to cope with the harsh polar environment whilst maintaining a low energy consumption, facilitating plug-and-play utility at a remote site, providing a low maintenance over-wintering mode and still meeting specific user requirements. The scientific discoveries have been largely facilitated by these technological features (see The facility in operation section for information on the research projects undertaken). Containerised laboratories are efficient research facilities that have a low environmental impact and promote collaboration.

\section{The concept}

Rothera Research Station is a logistics hub with a wharf and the necessary facilities to handle containerised laboratories. The design of the new laboratory had to take into account the challenges posed by the polar environment, as well as the existing station capacity. For example, winter operability at temperatures down to $-25^{\circ} \mathrm{C}$, snow accumulation, condensation, the need for low power consumption due to limited power availability at the station, and meeting the concerns of the Antarctic Treaty System. The design was submitted for Environmental Impact Assessment by nations who are consultative members of the Antarctic Treaty (COMNAP, 2005) to determine whether it met the required standards. The laboratory is not designed for accommodation purposes, but solely to be occupied by scientific personnel conducting experiments. Personnel are accommodated in facilities provided by the existing station. Furthermore, the construction of the laboratory was only allowed to have a 'minor or transitory' additional cumulative impact on the environment. Solutions such as solar panels for renewable energy provision and the transportable nature of the research facility reduces its environmental footprint on this pristine continent. Specific technological features were used to minimise this footprint (see section on Green building).

Although temperatures lower than $-25^{\circ} \mathrm{C}$ have been experienced at Rothera Point (Shanklin, Colwell, \& Moore, 2009), we opted for a winter operability temperature of $-25^{\circ} \mathrm{C}$, as a lower temperature operability would require a larger and more expensive heat pump installation, while the occupancy rate of the container laboratories is significantly lower during winter. Additionally, temperatures 


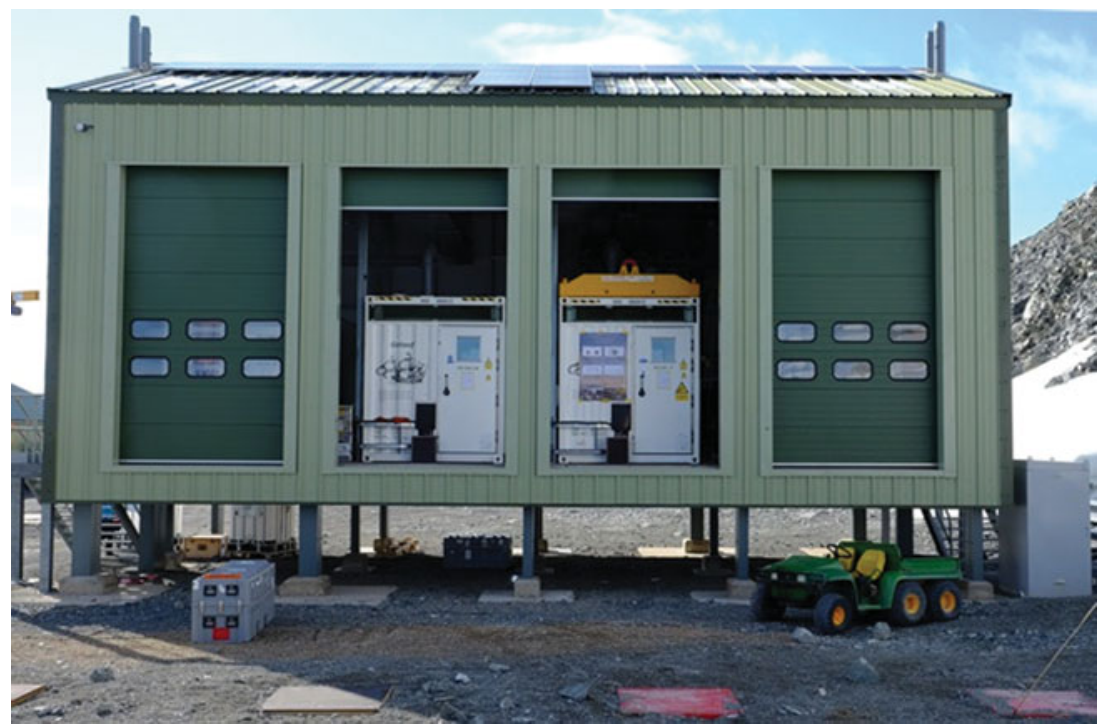

Fig. 2. Looking inside the docking station. Photo: A. Krasnobaev

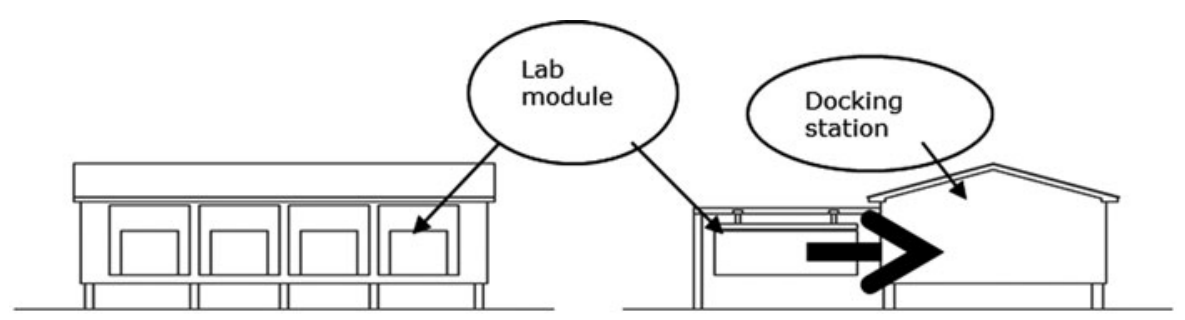

Fig. 3. The docking station designed and constructed by BAS. (C) BAS

below $-25^{\circ} \mathrm{C}$ are infrequent in this part of Antarctica (Shanklin et al., 2009). If temperatures fall below $-25^{\circ} \mathrm{C}$ the installation will perform at a lower capacity; below $-29^{\circ} \mathrm{C}$ the installation will switch off automatically. Antifrost protection measures need to be taken by closing the ventilation openings in the docking station and placing anti-frost heaters in the container laboratories.

The docking station was designed and constructed by BAS (see Fig. 3). A concrete foundation was constructed and an extended roof structure was erected. The docking station provides running water, scientific gases (oxygen and nitrogen), electricity, storage space and weather protection. Raising the structure off the ground allows natural wind scour to occur and minimises snow accumulation around the building, helping to ensure year-round access. Large, roller shutter doors allow the container labs to be placed inside the building using a unique, purpose built A-frame gantry system for lifting and moving the units (see Fig. 4). The four container laboratories were shipped to Rothera Research Station on the deck of BAS research vessels. Future transportation is recommended to be below deck (or in a 'sheltered location' as specified in the UNOLS portable scientific vans manual; Hawkins, 2003) as one of the container laboratories suffered minor water damage (sea water entered via a ventilation grid) because it was located on an unfavourable position on the vessel. This event did not result in any damage to the lab equipment. The laboratories are waterproof and can be deployed in remote locations and on research vessels, as has been done with this kind of facility for a considerable amount of time.

The docking station can house four 20-foot ISO standard high-cube containers, each of which houses a different laboratory. A high-cube container is one foot higher than a standard 20-foot container. The Royal Netherlands Institute for Sea Research (NIOZ), part of NWO, designed and built the four container laboratories. The requirements of the scientific end users led the design. For each specialised container laboratory a small team of intended users filled in a four-page questionnaire and discussed this with design engineers. Issues such as major usage, temperature, temperature stability, number of scientists in the container lab, lab equipment, fume hoods and the use of special and/or hazardous gases were identified and discussed. An iterative design optimisation process resolved incompatibilities and brought together user requirements resulting in several revisions of a 3D design drawing and the building specifications (see Fig. 5). The laboratories (1) contain a fully automatic $\mathrm{CO}_{2}$ concentration controlled ventilation system, (2) are equipped with floor heating/cooling, (3) are connected to the internet to monitor and control correct operation (from the Netherlands), (4) are designed according to user requirements with cabinets, worktables, pedestals, fume cupboards, cross-flow cabinets, water taps, purification and scientific gases, and (5) are equipped with emergency equipment (for example, fire alarm, fire 


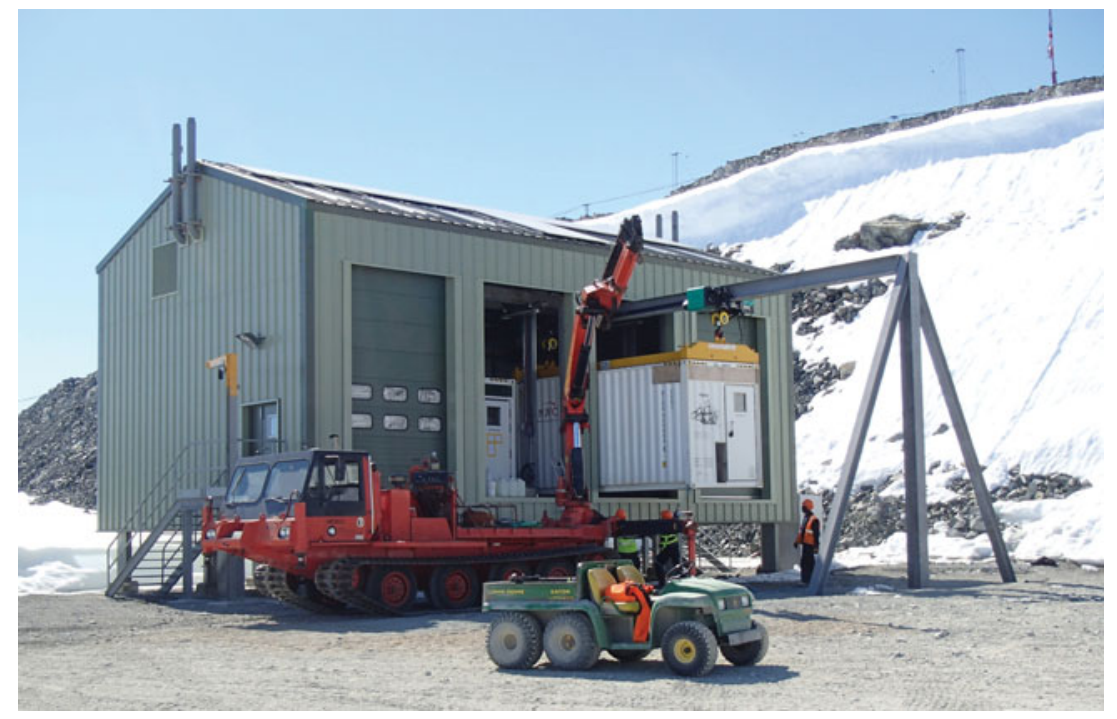

Fig. 4. The unique, purpose built A-frame gantry system for lifting and moving the units. Photo: T. Biggs

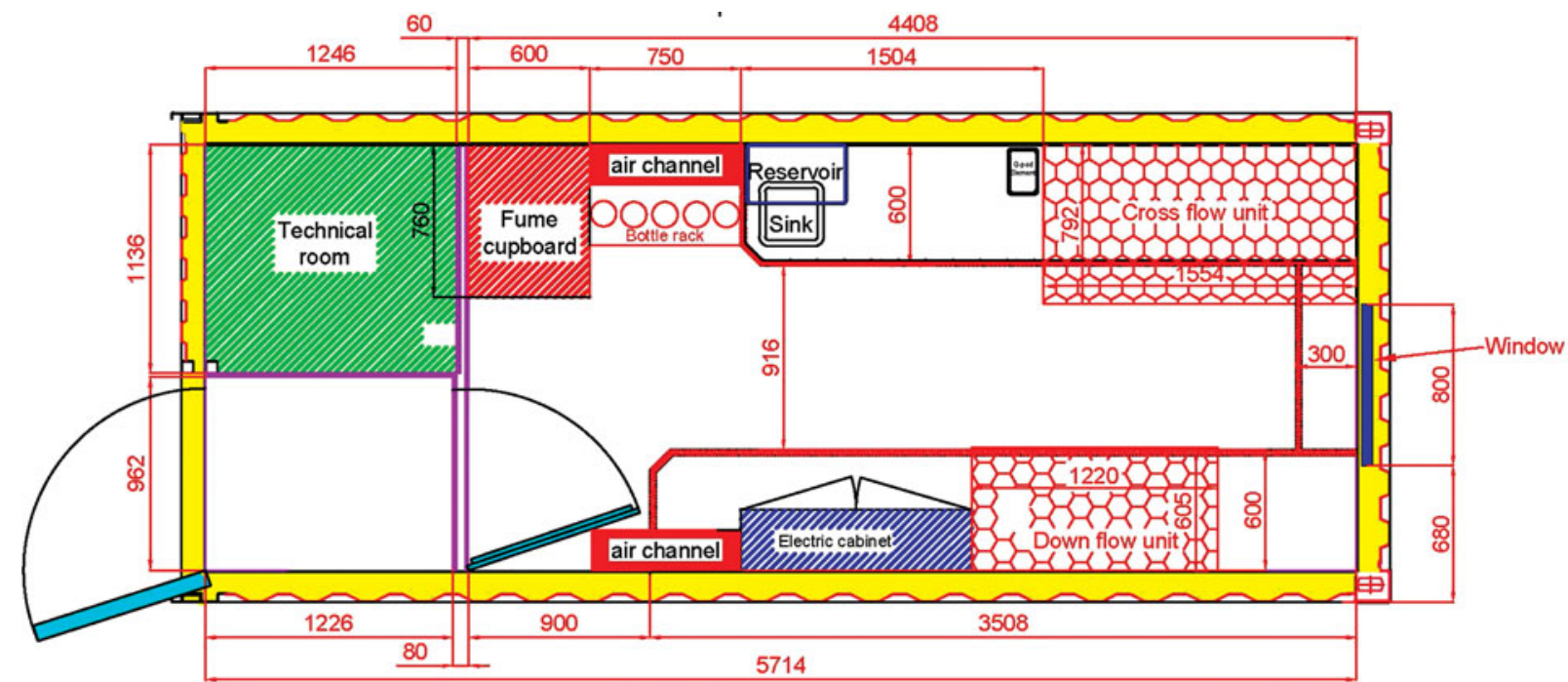

Fig. 5. Laboratory building specifications. (C) National Marine Facilities, NIOZ

extinguisher, blanket and a break-glass hammer). Each laboratory houses a cabinet providing remote monitoring and control capability via a satellite internet connection. In case of malfunction, emails are automatically sent to the engineers in the Netherlands.

\section{Green building}

Specific measures were taken to compensate for the additional power required by the laboratories and to minimise the environmental impact:

- Intelligent heat pumps were installed with buffer stock for warm and cold mixture storage to regulate the container laboratory temperature.

- The laboratories are fully insulated with 100-143 mm fire resistant polyisocyanurate (PIR) boards throughout to ensure low energy consumption and nylon joints are used to reduce thermal bridges - the insulation thickness depends on the area of application but in most cases 100-143 mm is sufficient.

- The laboratories are equipped with an outdoor heat exchanger for energy transfer and a heat recovery system to save energy.

- A floor heating system was installed to maintain a constant laboratory temperature.

The steelwork of each container was constructed first (see Fig. 6). It was then sand blasted before a four-layer epoxy-polyurethane coating was applied.

The interior of the container is made of $18 \mathrm{~mm}$ water-resistant multiplex panels. After the woodwork was finished, a three-layer vapour-proof epoxy coating was applied. The floor heating tubes (see Fig. 7) are covered with an epoxy-sand mixture. A casted floor was applied to guarantee the vapour-proof seal. 


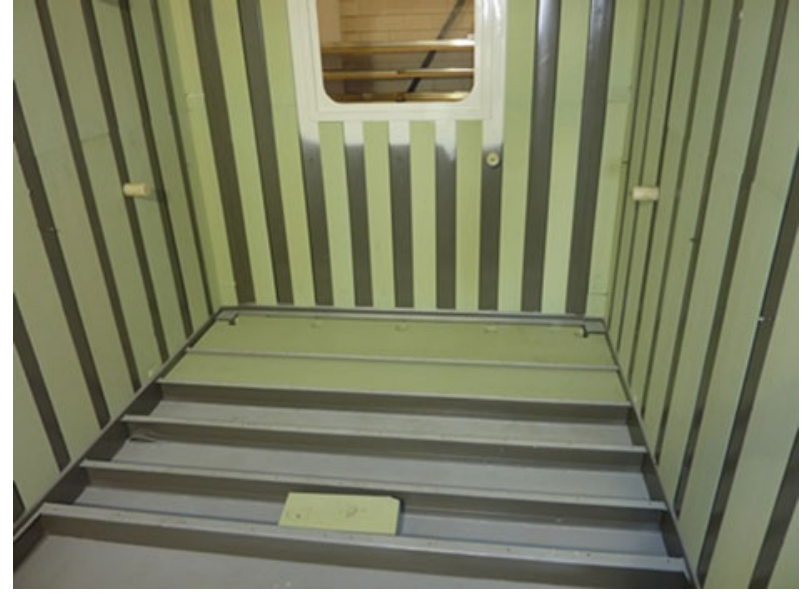

Fig. 6. The steelwork of each container was constructed first. Photo: JM Services

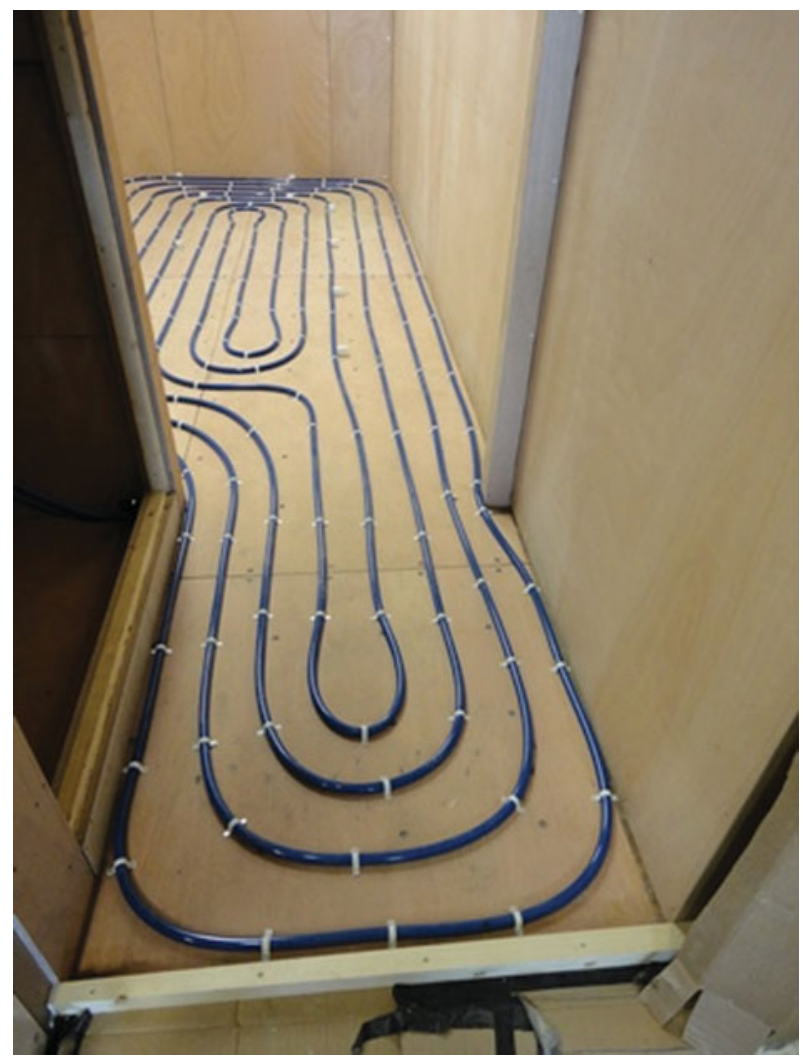

Fig. 7. The floor heating tubes. Photo: JM Services

\section{Heat pump installation}

The most effective way to save energy is to install a heat pump system (www.energy.gov/energysaver/ air-source-heat-pumps). This installation uses the energy from the outside air to achieve the desired temperature within the laboratory. In the case of heating, energy consumption can be reduced by $50 \%$ compared to conventional systems. For example, heating the insulated 20foot ultra-clean container lab to $20^{\circ} \mathrm{C}$ when the outside temperature is $-25^{\circ} \mathrm{C}$ with a ventilation rate of $50 \mathrm{~m}^{3} / \mathrm{h}$ will require $4.6 \mathrm{~kW}$ of energy using a conventional electric heater, but only $2.2 \mathrm{~kW}$ using an air-source heat pump. To achieve $20^{\circ} \mathrm{C}$ when the outside temperature is $-5^{\circ} \mathrm{C}$ with a ventilation rate of $250 \mathrm{~m}^{3} / \mathrm{h}, 2.44 \mathrm{~kW}$ of electric power would be reduced to $1.03 \mathrm{~kW}$ using a heat pump (a reduction of 58\%). The heat exchanger for the heat pump is mounted in an outdoor niche on top of the container. Refrigerant liquid evaporates to gas in this air cooler. The heat required for evaporation comes from the outdoor air, which is blown through the evaporator by fans and gives off energy.

The refrigerant gas is exposed to a high pressure in a compressor. The gas then flows into the heat exchanger and transfers energy to an ethylene glycol/water mixture. The heat accumulates within this vessel. The warm mixture (fluid) leaves the vessel at the top through two- or three-way valves to several heat exchangers. The cooled mixture returns at the bottom of the vessel. The mixture circulates continuously. A cooling mode is also provided. The extracted energy is saved in a buffer stock vessel. The result is a stable laboratory temperature (see Fig. 8).

A heat recovery system was also installed. This system exchanges the energy from extracted air and uses it to pre-acclimatise fresh air. The air refresh system is automatically controlled depending on the $\mathrm{CO}_{2}$ level. Fume cupboards required for use with acid gases have exhaust compartments made from stainless steel and use explosion-proof fans.

Using the heat pump system for heating and cooling proved to be a durable and energy efficient solution. Durable because only one installation is needed for both heating and cooling, and efficient because of the low energy consumption for heating. However, upon operation the ambient temperature in the docking station proved to be higher than anticipated, resulting in a reduced cooling capacity of the heat pump system. Enlargement of the ventilation openings of the docking station solved this issue. At the same time, a larger cooling capacity for some of the low temperature container laboratories was installed.

\section{Solar panel array}

Solar photovoltaic (PV) panels were installed on both the north $\left(67.5 \mathrm{~m}^{2}\right)$ and south facing roofs $\left(31.5 \mathrm{~m}^{2}\right)$ in order to best use the 24 hours of daylight at Rothera during the summer months. The panels were Hyundai HiS-S218SF units. Electrical consumption figures per annum are given in Table 1. The solar panels have produced a reasonably consistent annual yield and were able to provide around $22 \%$ of the energy needed by the building including the four container laboratories and associated laboratory equipment. The total power use in 2015 was relatively low because there was no overwinter requirement for the laboratory, as there had been in 2013 and 2014. Thus, in 2015 winter (April to October) power consumption was solely to keep the container laboratories at just above $0^{\circ} \mathrm{C}$.

The laboratory has peak occupancy during the Antarctic summer months (November to March). Table 2 gives 


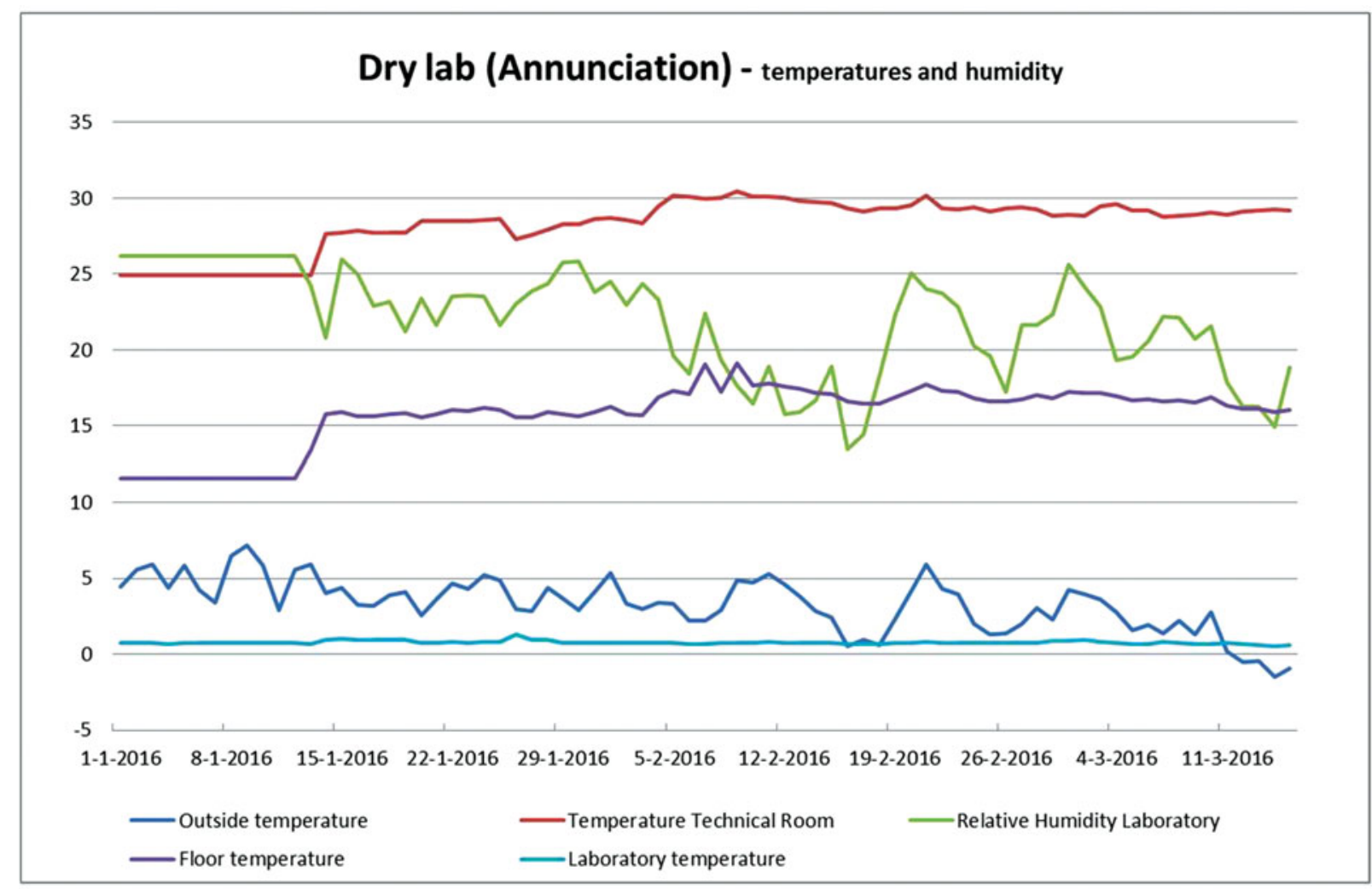

Fig. 8. Laboratory temperature and humidity control in lab 1.

Table 1. Percentage of power provided by the solar PV panels on the roof of the laboratory building.

\begin{tabular}{|lllll|}
\hline $\begin{array}{l}\text { Year (January to } \\
\text { December) }\end{array}$ & $\begin{array}{l}\text { Main electrical } \\
\text { meter }(\mathrm{kW} / \mathrm{h})\end{array}$ & $\begin{array}{l}\text { PV electrical } \\
\text { meter }(\mathrm{kW} / \mathrm{h})\end{array}$ & $\begin{array}{l}\text { Total power } \\
\text { use }(\mathrm{kW} / \mathrm{h})\end{array}$ & $\begin{array}{l}\text { Percentage PV power } \\
\text { to total usage }(\%)\end{array}$ \\
\hline 2013 & 29,200 & 8500 & 37,700 & 22.5 \\
2014 & 30,300 & 8700 & 39,000 & 22.3 \\
2015 & 19,600 & 8900 & 28,500 & 31.0 \\
\hline
\end{tabular}

Data provided by D. Ingham, BAS.

Table 2. Power consumption of the laboratory for January in four consecutive years.

\begin{tabular}{|lllll|}
\hline Year & $\begin{array}{l}\text { Diesel generator } \\
\text { power }(\mathrm{kW} / \mathrm{h})\end{array}$ & PV power $(\mathrm{kW} / \mathrm{h})$ & $\begin{array}{l}\text { Total power use } \\
(\mathrm{kW} / \mathrm{h})\end{array}$ & $\begin{array}{l}\text { Percentage PV power } \\
\text { to total usage }(\%)\end{array}$ \\
\hline 2013 & 2836 & 3058 & 5894 & 52.0 \\
2014 & 3770 & 2847 & 6617 & 43.0 \\
2015 & 1897 & 1437 & 3334 & 43.0 \\
2016 & 1879 & 1814 & 3693 & 49.0 \\
\hline
\end{tabular}

Data provided by D. Ingham, BAS.

the power consumption for January in four consecutive years.

\section{Testing the facility}

A prototype container laboratory was tested under harsh conditions in a specially built cold store in the Netherlands, with temperatures ranging from $-25^{\circ} \mathrm{C}$ to $+20^{\circ} \mathrm{C}$ (see Tables $3 \& 4$ and Fig. 9).

\section{The facility in operation}

After two building seasons in 2011 and 2012, the transportable lab facility started operating in November 2012. It provides both additional and complementary research facilities, including a temperature-controlled laboratory for culturing phytoplankton and a clean room facility for measuring extreme low concentrations of trace elements and pollution. The labs are designed to accommodate 
Table 3. Test results for temperature development inside the dry container laboratory (lab 1).

\begin{tabular}{|rlll|}
\hline $\begin{array}{l}\text { Outdoor } \\
\text { temperature }\left({ }^{\circ} \mathrm{C}\right)\end{array}$ & $\begin{array}{l}\text { Laboratory desired } \\
\text { temperature }\left({ }^{\circ} \mathrm{C}, \text { set }\right.\end{array}$ & $\begin{array}{l}\text { Laboratory } \\
\text { temperature reached } \\
\text { point) }\end{array}$ & $\begin{array}{l}\left.{ }^{\circ} \mathrm{C}\right) \\
\text { Relative humidity } \\
(\%)\end{array}$ \\
\hline 20 & 15 & $20.8-21.3$ & $50-65$ \\
10 & 15 & $17.5-18.7$ & $50-65$ \\
5 & 15 & $15.5-16.2$ & $45-60$ \\
0 & 15 & $14.7-15.8$ & $40-55$ \\
-5 & 15 & $14.8-15.6$ & $30-50$ \\
-10 & 15 & $14.7-15.4$ & $30-45$ \\
-15 & 15 & $14.5-15.1$ & $80-95$ \\
-20 & 15 & $14.3-15.0$ & $70-85$ \\
-25 & 15 & $14.2-14.7$ & $30-55$ \\
20 & 20 & $20.7-21.4$ & $50-65$ \\
10 & 20 & $19.7-21.2$ & $50-65$ \\
5 & 20 & $19.4-21.3$ & $45-60$ \\
0 & 20 & $19.7-20.8$ & $40-55$ \\
-5 & 20 & $19.3-21.0$ & $30-50$ \\
-10 & 20 & $19.7-20.4$ & $30-45$ \\
-15 & 20 & $18.9-21.1$ & $80-95$ \\
-20 & 20 & $18.3-20.0$ & $70-85$ \\
-25 & 20 & $18.4-19.8$ & $30-55$ \\
20 & 25 & $23.8-26.3$ & $50-65$ \\
10 & 25 & $24.0-25.7$ & $50-65$ \\
5 & 25 & $23.5-25.4$ & $45-60$ \\
-5 & 25 & $22.9-25.9$ & $40-55$ \\
-10 & 25 & $23.4-24.6$ & $30-50$ \\
-20 & 25 & $23.0-24.7$ & $30-45$ \\
-25 & 25 & $23.3-24.1$ & $80-95$ \\
& 25 & $22.6-23.7$ & $30-55$ \\
\hline
\end{tabular}

Table 4. Energy consumption during test run of the temperature development inside the dry container laboratory (lab 1).

\begin{tabular}{|c|c|c|c|c|c|c|}
\hline \multirow[b]{2}{*}{$\begin{array}{l}\text { Outdoor } \\
\text { temperature }\left({ }^{\circ} \mathrm{C}\right)\end{array}$} & \multirow{2}{*}{$\begin{array}{l}\text { Desired laboratory } \\
\text { temperature } \\
\left({ }^{\circ} \mathrm{C} \text {, set point }\right)\end{array}$} & \multirow{2}{*}{$\begin{array}{l}\text { Achieved } \\
\text { laboratory } \\
\text { temperature }\left({ }^{\circ} \mathrm{C}\right)\end{array}$} & \multirow[b]{2}{*}{$\begin{array}{l}\text { Relative } \\
\text { humidity (\%) }\end{array}$} & \multicolumn{3}{|c|}{ Power consumption } \\
\hline & & & & $\begin{array}{l}\text { Average } \\
\text { (Watt) }\end{array}$ & $\begin{array}{l}\text { Minimum } \\
\text { (Watt) }\end{array}$ & $\begin{array}{l}\text { Maximum } \\
\text { (Watt) }\end{array}$ \\
\hline-5 & 20 & $19.3-21.0$ & $30-50$ & 1050 & 180 & 1050 \\
\hline-25 & 20 & $18.4-19.8$ & $30-55$ & 2250 & 410 & 5200 \\
\hline
\end{tabular}

Laboratory lights were switched off.

Fume cupboard was switched on at $400 \mathrm{~m}^{3} / \mathrm{h}$ air refreshing.

It is not possible to maintain a high relative humidity for more than one hour in the test room.

specific research demands but are general enough to allow use for other research projects with limited remodelling.

Lab 1 is suitable for operating a wide range of analytical instruments (for example, flow cytometry) that need to be run at room temperature (see Fig. 10).

Lab 2 is used for processing water samples and performing biological rate measurements at the temperature of the sample of interest. The temperature in this container is kept at $0-15^{\circ} \mathrm{C}$ (see Fig. 11).

Lab 3 is set up for culturing using an open cabinet with plasma lamps that provide the daylight spectrum. This lab is also fitted with a mass spectrometer. The temperature in this container can be kept between $0-22^{\circ} \mathrm{C}$ (see Fig. 12).

Lab 4 is a clean room laboratory suitable for trace metal analysis but also for measuring low concentrations of contaminants. It is equipped with special filters in the air processing system to ensure that the air entering the container reaches an ISO 7 (according to the ISO 14644-1 standard) or FED (according to the US FED STD 209E standard) 10,000 clean room class. Additionally this lab is free of (uncoated) metal (see Figs 5 \& 13).

Remote condition monitoring, failure recovery and changes of settings are performed via the internet by the manufacturer (JM Services, the Netherlands), and proved to be effective. If a malfunction occurs, the controller of the container sends an email to JM Services with the status of the installation. After login, fault finding can be performed and a solution sought, in close collaboration with the scientist(s) working in the container. If replacement of parts is essential, a BAS electrical engineer can 


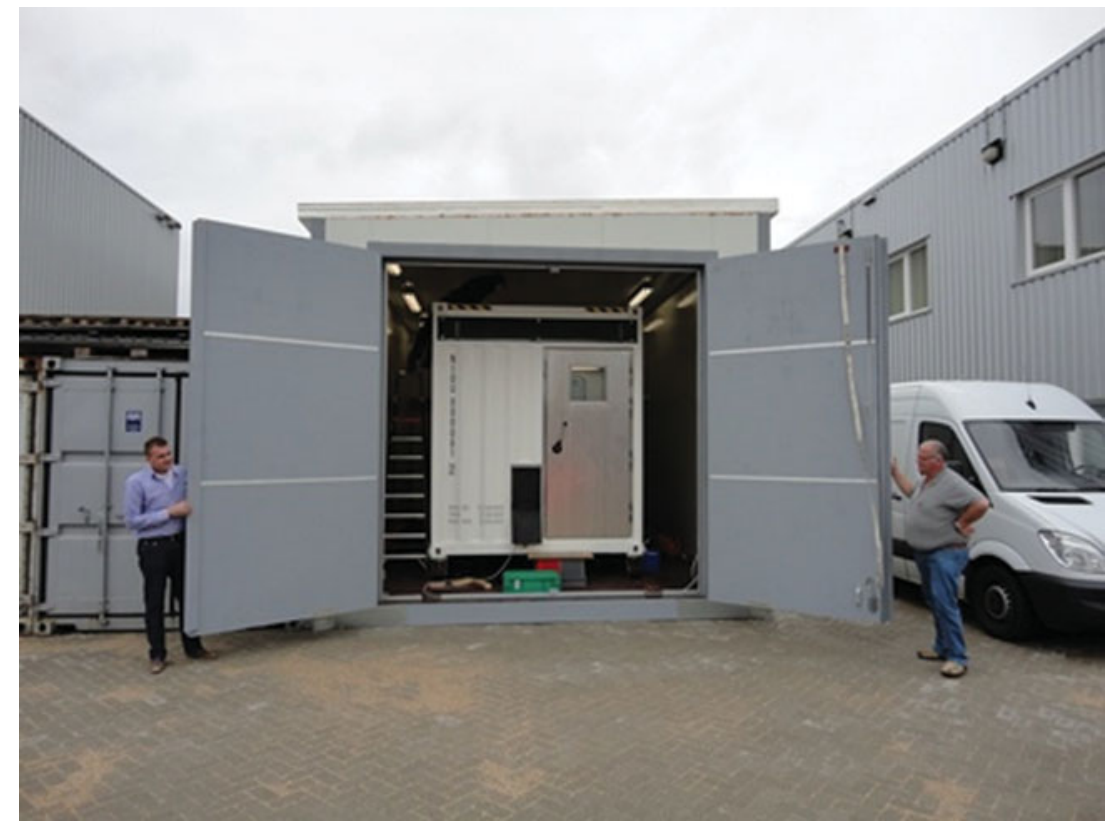

Fig. 9. The prototype container laboratory tested in a specially built cold store. Photo: M.G. Smit

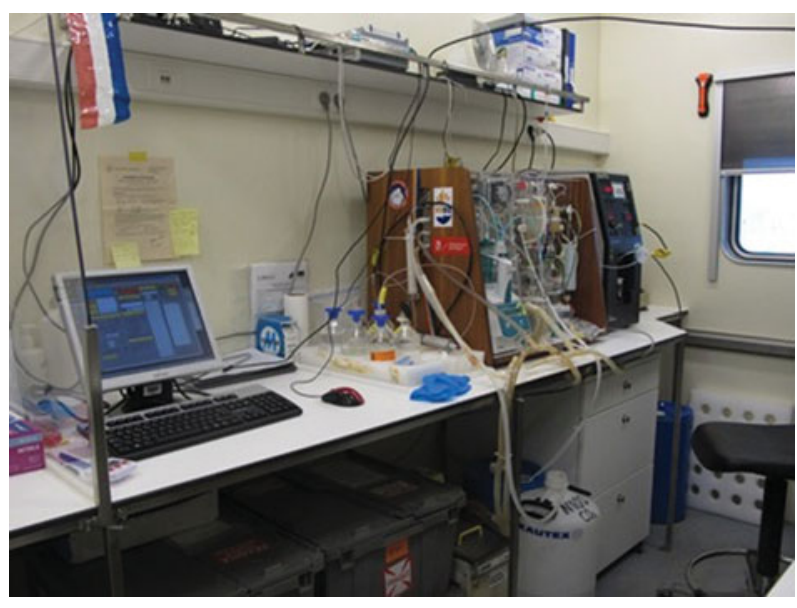

Fig. 10. Lab 1: suitable for operating a wide range of analytical instruments that need to be run at room temperature. Photo E. Jones

perform the repairs via instructions by email or phone. Some researchers need specific climate settings inside the container labs, which can be adjusted according to their desires. The internet connection between the container labs and the Netherlands prevents expensive service visits. Besides this, local support is provided by BAS technical staff and manuals are provided for each container to provide scientists with self-support knowledge.

If a lab module requires special services or further special adaptation for the on-going research programme it can be taken out of the docking station and shipped back for a technical overhaul or update at the end of a summer season, to be returned at the start of the next season. Regular maintenance is done by BAS staff on station. From the start of operation of the facility the

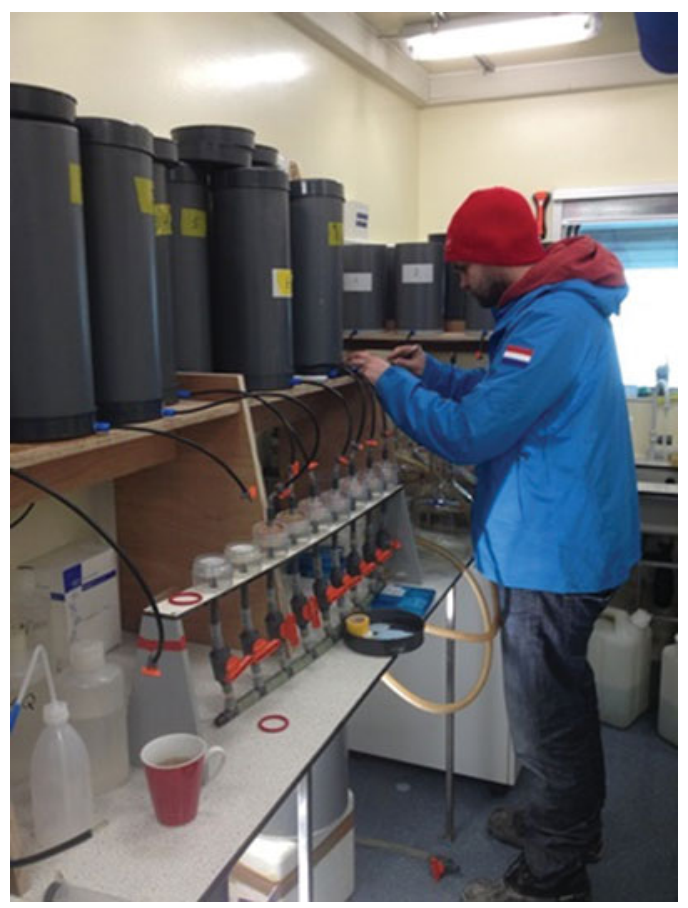

Fig. 11. Lab 2: used for processing water samples and performing biological rate measurements at the temperature of the sample of interest $\left(0-15^{\circ} \mathrm{C}\right)$. Photo: R. Visser

container labs have not been transported back. After five years of operation, a major overhaul of the container labs is necessary. The plan is to move them back to the Netherlands, one or two at a time for a check-up. Refurbishment is a possibility during the overhaul. 


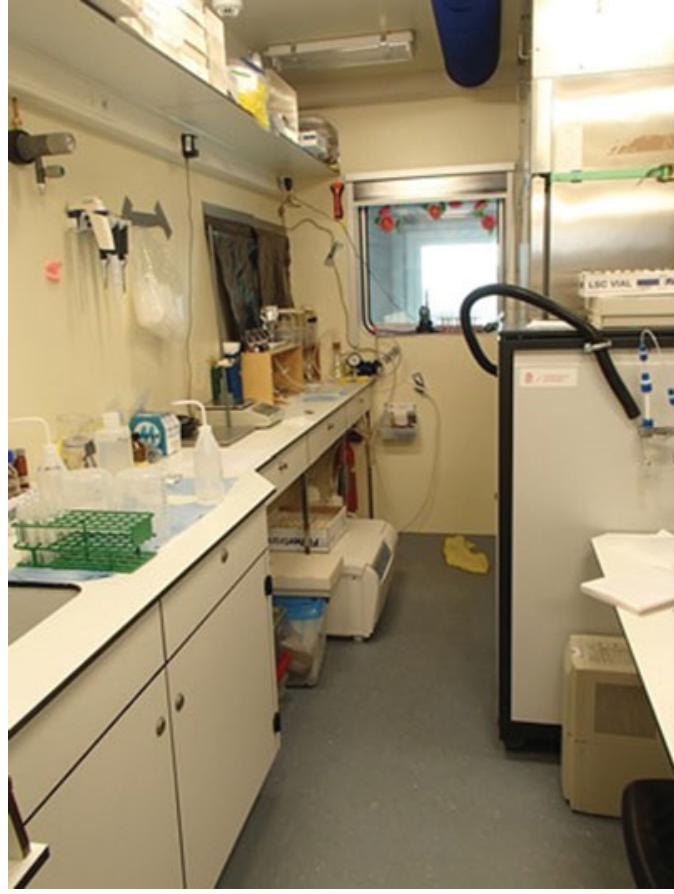

Fig. 12. Lab 3: set up for culturing using an open cabinet with plasma lamps that provide the daylight spectrum and fitted with a mass spectrometer $\left(0-22^{\circ} \mathrm{C}\right)$. Photo: D. den Os

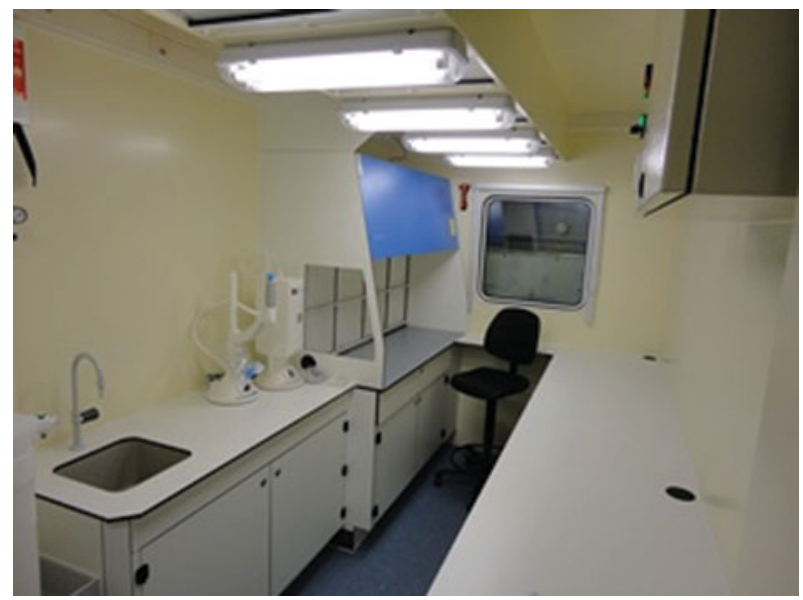

Fig. 13. Lab 4: a clean room suitable for trace metal analysis and for measuring low concentrations of contaminants. It is equipped with special filters in the air processing system and is free of (uncoated) metal. Photo: H. de Porto

Since opening, the container labs have provided enhanced facilities beyond those already available on station and have allowed extra, complementary research projects to be undertaken. All projects had a link to global climate change by studying either variables directly related to global warming (for example, $\mathrm{CO}_{2}$, climate gases) or its consequences (for example, consequences for lower foodweb members, biogeochemical cycling of elements). The laboratory users changed according to the different project requirements. Thus far, lab 1 and 2 have been used by marine microbiology research groups. One group studied the production, abundance and community composition of phytoplankton and bacteria in Marguerite Bay, as part of scientific research aimed at understanding microbial community shifts due to climate change (Rozema et al., 2016; van de Poll et al., 2016). As a result of recent warming effects the nearby Sheldon Glacier is visibly retreating and the associated increase in meltwater will strongly influence the marine microbial communities in Marguerite Bay (Rozema et al., 2017). Another research group used labs 1 and 2 in combination with outdoor flush through incubators to study the ecological impact of virus-induced mortality in different phytoplankton groups and in the heterotrophic microbial community (Evans \& Brussaard. 2012a, 2012b). Shifts in phytoplankton community composition are expected to change not only food quality for higher trophic levels, but also the share of the different loss factors (virus-induced mortality $v s$ grazing); thereby affecting ecosystem productivity (Evans et al., 2017; Mojica, Huisman, Wilhelm, \& Brussaard, 2016). Both projects needed a wet lab for processing large amounts of sea water samples and a dry lab for the analyses.

Subsequently, labs 1 and 2 were used for research on $\mathrm{CO}_{2}$ concentrations and its effects on the marine ecosystem in Marguerite Bay (Jones et al., 2017). Without access to the transportable laboratories this research project could not have proceeded as the existing facilities (Bonner Laboratory) were already at maximum capacity. Another project that benefitted from the additional laboratory space was a terrestrial ecology team who used lab 1 to process samples collected during field campaigns around Rothera Research Station. This study investigated how marine vertebrates (penguins, elephant seals and fur seals) affect nitrogen dynamics as well as the structure of the typically nitrogen-deprived terrestrial foodweb (Beyer \& Bölter, 2000; Convey, 1996).

Lab 3 was used by a research group studying the flux of dimethylsulphide and brominated compounds from seaice to surface ocean. The western Antarctic Peninsula is among the most rapidly warming areas on Earth (Meredith \& King, 2005; Vaughan et al., 2003) and besides warming of the ocean surface the sea-ice is declining (Stammerjohn, Martinson, Smith, \& Iannuzzi, 2008). Use of lab 3, with the specially built-in incubation cabinet and the mass spectrometer in combination with stable isotopes, allowed for direct biosynthesis measurements.

Lab 4 has been used to sample for trace elements in Marguerite Bay. The ultra-clean environment of this container lab made measuring eight trace elements (Fe, $\mathrm{Mn}, \mathrm{Cd}, \mathrm{Zn}, \mathrm{Pb}, \mathrm{Ni}, \mathrm{Cu}$ and $\mathrm{Co}$ ), vital for every living organism, possible through inductively coupled plasma mass spectrometry (ICP-MS). The function of melting glaciers as a source of metals for the pelagic phytoplankton was studied in relation to increased glacier melt due to global warming (Bown et al., 2017). Following this research project, another research group uses container lab 4 to quantitatively assess the transport of persistent 
organic pollutants (from the atmosphere to the benthic part of the marine environment) in Marguerite Bay, which also requires ultra-clean conditions.

Altogether these research projects are aimed at providing valuable insights into how the ecologically important Antarctic marine system responds to climate change, and the data generated can be used to refine climate and ecosystem models.

\section{User expectations}

Since the opening of the laboratory 28 Dutch-funded researchers have used the facility. A small survey was held, to which nine people responded. Two-thirds of the respondents believed that their expectations of the facility were met. Where expectations were not met, respondents stated that the bench area should be increased; the temperature of lab 2 was not stable and much higher than expected; and there was a lack of storage space. Of the respondents, $89 \%$ said that they were able to manage their experiments in the available space, but it was cramped and larger equipment did not fit. Respondents reported a need for a stable temperature and better drainage. They suggested that future container laboratories should be more general in their design to be able to accommodate all types of research. The potential to transport one of the container labs elsewhere, to the Arctic and to use them on research vessels was appealing to $44 \%$ of the respondents. The success of this facility depends on the provision of facilities that are not currently available, for example ultraclean facilities, or on providing general laboratory space where there is a shortage.

\section{Future prospects}

The idea of the transportable laboratory facility was to provide an adaptable and sustainable docking station for various custom-made and transportable laboratories servicing varying scientific projects. Because of their transportability, the four labs are flexible and can be installed and used as required, and renewed or removed when necessary. An additional benefit for the longer term is the potential for other BAS or NWO science partners to use this facility for research, either by using one of the available container laboratories or bringing in their own container lab for temporary use on site.

Replicating such docking stations on other research stations in Antarctica would make it possible to exchange container labs between them and could be (one of) the answer(s) to the question posed in the final report of the COMNAP Antarctic Roadmap Challenges Project: Do we continue to build infrastructure in Antarctica and, if so, in what form and where? (Kennicutt, Yeadong, \& Rogan-Finnemore, 2016). Containers are already used as transportable laboratories for Antarctic research and a good housing facility could increase their use. They can even be exchanged between Antarctic and Arctic projects. This will provide a flexible way of executing research in polar regions, comparable with the present way of using the capacity of research vessels among different nations. Biosecurity measures would be essential before transporting laboratories between different regions, such as those already in place by the Antarctic Treaty Consultative Members (for example, http://www.ats.aq/ documents/atcm34/ww/atcm34_ww004_e.pdf). An existing user model that could support such a concept is the Transnational Access programme of the International Network for Terrestrial Research and Monitoring in the Arctic (INTERACT, www.eu-interact.org/transnational-access/ infrastructures). This is a network of terrestrial field bases in the Arctic and mountain areas of the northern hemisphere. It has an EU funded 'transnational access' component that offers funding to user groups for access to 20 of the INTERACT stations. Although a number of nations have been using containerised laboratories, there is very little peer-reviewed literature to be found describing their performance, and more published data would be helpful in promoting a more efficient use of these facilities in polar regions.

Containerised laboratory facilities, as presented here, may well be a new way of undertaking scientific research projects in extremely challenging environments that is both sustainable (environmentally friendly) and more economically efficient than each party building its own research station.

\section{Acknowledgements}

We are indebted to D. Ingham (BAS), H. de Porto (NIOZ), M. Bakker (NIOZ) and J. Markwat (JM Services) for the design and building of the transportable laboratory facility. We acknowledge the scientific efforts of the research teams led by J. Stefels and A.G.J. Buma from the University of Groningen, R. Aerts from the Free University Amsterdam, N. van den Brink from Wageningen University and H.J.W. de Baar and C.P.D. Brussaard from NIOZ.

\section{Financial support}

This project received financial support from the Dutch Ministry for Education, Science and Culture and the Netherlands Organisation for Scientific Research. BAS and Rothera Research Station are funded by the UK Natural Environment Research Council.

\section{Conflict of interest}

None.

\section{References}

Bown, J., Laan, P., Ossebaar, S., Bakker, K., Rozema, P., \& De Baar, H. J. W. (2017). Bioactive trace metals time series during austral summer in Ryder Bay, western Antarctic Peninsula. Deep-Sea Research II - Topical Studies in Oceanography, 139, 103-119.

COMNAP. (2005). ATCM guidelines for environmental impact assessment in Antarctica. Retrieved from https://www. comnap.aq/Publications/Comnap\%20Publications/Forms/ Publications.aspx?Category=Operational\%20Guidelines. 
De Baar, H. J. W. (2013). Dirck Gerritsz and Antarctica. In: Van der Kroef, D. A., Noor, L. H. W., \& Prop, R. (Eds.). The story behind the Dirck Gerritsz Laboratory. The Hague: Netherlands Organisation for Scientific Research, 17-35.

Beyer, L., \& Bölter, M. (2000). Chemical and biological properties, formation, occurrence and classification of spodic cryosols in a terrestrial ecosystem of East Antarctica (Wilkes Land). CATENA, 39, 95-119.

Convey, P. (1996). The influence of environmental characteristics on life history attributes of Antarctic terrestrial biota. Biological Reviews, 71, 191-225.

Evans, C., Brandsma, J., Pond, D. W., Venables, H. J., Meredith, M. P., Witte, H. J., . . . Brussaard, C. P. D. (2017). Drivers of interannual variability in virioplankton abundance at the coastal Western Antarctic Peninsula and the potential effects of climate change. Environmental Microbiology, 19, 740-755.

Evans, C., \& Brussaard, C. P. D. (2012a). Viral lysis and microzooplankton grazing of nano and picophytoplankton and subsequent iron regeneration throughout the Southern Ocean. Limnology and Oceanography, 57, 1826-1837.

Evans, C., \& Brussaard, C. P. D. (2012b). Regional variation in lytic and lysogenic viral infection in the Southern Ocean and its contribution to biogeochemical cycling. Applied and Environmental Microbiology, 78, 6741-6748.

Hawkins, M. J. (2003). UNOLS portable scientific vans manual. Narragansett, RI: University-National Oceanographic Laboratory System.

Jones, E. M., Fenton, M., Meredith, M. P., Clargo, N. M., Ossebaar, S., Ducklow, H. W., . . De Baar, H. J. W. (2017). Ocean acidification and carbonate saturation states in the coastal zone of the west Antarctic Peninsula. Deep-Sea Research II - Topical Studies in Oceanography, 139, 181194.

Kennicutt, M. C. (2009). Future directions in Antarctic science: implications for national programs. Cambridge: SCAR. Retrieved from http://www.scar.org/scar_media/documents/ publications/Antarctic_Science_Future_Kennicutt.pdf.

Kennicutt, II, M. C., Yeadong, K., \& Rogan-Finnemore, M. (2016). Antarctic roadmap challenges. Christchurch: COMNAP.

Meredith, M. P., \& King, J.C. (2005). Rapid climate change in the ocean west of the Antarctic Peninsula during the second half of the 20th century. Geophysical Research Letters, 32, 1-5.
Meredith, M. P., Stefels, J., \& van Leeuwe, M. (2017). Marine studies at the western Antarctic Peninsula: Priorities, progress and prognosis. Deep-Sea Research II - Topical Studies in Oceanography, 139, 1-8.

Mojica, K. D. A., Huisman, J., Wilhelm, S. W., \& Brussaard, C. P. D. (2016). Latitudinal variation in virus-induced mortality of phytoplankton across the north Atlantic Ocean. International Society for Microbial Ecology Journal, 10, 500-513.

Van de Poll, W. H., Maat, D. S., Fischer, P. H., Rozema, P. D., Daly, O. B., Koppelle, S., . . Buma, A. G. J. (2016). Atlantic advection driven changes in glacial meltwater: effects on phytoplankton chlorophyll-a and taxonomic composition in Kongsfjorden, Spitsbergen. Frontiers in Marine Science, 3, 200.

Rozema, P. D., Biggs, T., Sprong, P. A. A., Buma, A. G. J., Venables, H. J., Evans, C., . . ... Bolhuis, H. (2016). Summer microbial community composition governed by upper-ocean stratification and nutrient availability in northern Marguerite Bay, Antarctica. Deep-Sea Research II - Topical Studies in Oceanography, 139, 151-166.

Rozema, P. D., Venables, H. J., van de Poll, W. H., Clarke, A., Meredith, M. P., \& Buma, A. G. J. (2017). Interannual variability in phytoplankton biomass and species composition in northern Marguerite Bay (west Antarctic Peninsula) is governed by both winter sea ice cover and summer stratification. Limnology and Oceanography, 62, 235-252.

Shanklin, J., Colwell, S., \& Moore, C. (2009). Meteorological observing and climate in the British Antarctic Territory and South Georgia: part 2. Weather, 64, 171177.

Stammerjohn, S. E., Martinson, D. G., Smith, R. C., \& lannuzzi, R. A. (2008). Sea ice in the western Antarctic Peninsula region: spatio-temporal variability, from ecological and climate change perspectives. Deep-Sea Research II - Topical Studies in Oceanography, 55, 20412058.

Vaughan, D. G., Marshall, G. J., Connolley, W. M., Parkinson, C., Mulvaney, R., Hodgson, D. A., . . Turner, J. (2003). Recent rapid regional climate warming on the Antarctic Peninsula. Climatic Change, 60, 243-274. 